\title{
Schmallenberg virus: emergence of an Orthobunyavirus among ruminants in Western Europe
}

\author{
Schmallenbergvirus: het opduiken van een Orthobunyavirus bij herkauwers \\ in West-Europa
}

\author{
${ }^{1}$ L. Steukers, ${ }^{2}$ G. Bertels, ${ }^{3}$ A.B. Cay, ${ }^{1}$ H.J. Nauwynck \\ ${ }^{1}$ Laboratory of Virology, Department of Virology, Parasitology and Immunology, Faculty of Veterinary \\ Medicine, Ghent University, Salisburylaan 133, B-9820 Merelbeke, Belgium \\ ${ }^{2}$ Dierengezondheidszorg Vlaanderen (DGZ), Deinse Horsweg 1, B-9031 Drongen, Belgium \\ ${ }^{3}$ Centrum voor Onderzoek in Diergeneeskunde en Agrochemie (CODA-CERVA), \\ Groeselenberg 99, B-1180 Ukkel, Belgium \\ lennert.steukers@ugent.be
}

\begin{abstract}
Recently, a novel virus has been identified among ruminants in Western Europe. This virus, the so-called Schmallenberg virus, belongs to the family Bunyaviridae, genus Orthobunyavirus, serogroup Simbu and is closely related to Akabane, Aino and Shamonda virus. In cattle, acute symptoms in the dam and adult animals generally include high fever, milk drop and diarrhea. More importantly, infection during gestation may lead to abortion, stillbirth and congenital malformations. As all bunyaviruses, Schmallenberg virus also uses vectors for efficient transmission. Closely related viruses causing similar symptoms, such as Akabane and Akabane-like viruses, are mainly transmitted by Culicoides. It is very likely that Schmallenberg virus is transmitted by similar vectors. This review provides an overview of Bunyaviridae, their epidemiology, symptoms, prevention and control. Special emphasis is put on the Simbu serogroup of the Orthobunyavirus genus pointing out the similarities between them and closely related members.
\end{abstract}

\section{SAMENVATTING}

Recent werd er een nieuw virus geïdentificeerd bij herkauwers in West-Europa. Dit virus, het Schmallenbergvirus, behoort tot de familie Bunyaviridae, genus Orthobunyavirus, serogroep Simbu en vertoont sterke verwantschap met het Akabane-, Aino- en Shamondavirus. Bij runderen bestaan de acute symptomen bij het moederdier en volwassen dieren in het algemeen uit onder andere hoge koorts, milk drop en diarree. Opmerkelijk is het effect van het virus op de foetus. Infectie tijdens de dracht kan aanleiding geven tot abortus, doodgeboorte en ernstige congenitale malformaties. Net zoals alle andere bunyavirussen wordt Schmallenbergvirus overgedragen door vectoren. Gelijkaardige virussen, zoals Akabane en Akabane-achtige virussen, worden op die manier overgedragen door Culicoides. Vermoedelijk zijn ook gelijkaardige vectoren van belang voor de transmissie van Schmallenbergvirus. Deze review geeft een overzicht van Bunyaviridae, hun epidemiologie, symptomen, preventie en bestrijding. Speciale aandacht gaat hierbij naar gelijkenissen tussen het Schmallenbergvirus en andere leden van de Simbu-serogroep.

\section{INTRODUCTION}

During the summer of 2011, an unusually high number of cases displaying a similar syndrome among cattle were first observed in Germany. Multiple farms reported cows showing high fever $\left(>40^{\circ} \mathrm{C}\right)$, milk drop (to $50 \%$ ), general depression, loss of appetite and in some cases diarrhea. The Friedrich-Loeffler-Institut (FLI), Federal Research Institute for Animal Health Investigations in Germany, was the first laboratory to detect unknown microbial genetic material in samples of affected animals by means of metagenomic analysis. Comparative genetic analysis indicated that this new virus is very similar to certain members of the Orthobunyavirus genus. Moreover, the virus could be isolated on insect cells and on a hamster cell line.
Based on the geographic origin of the samples, the new virus was named "Schmallenberg virus". Subsequently, more severe symptoms were observed a few months after the primary onset of the disease. Abortions, stillbirths and congenital malformations, such as arthrogryposis and hydranencephaly, were observed in bovines, caprines, but especially in ovines. Germany, the Netherlands, Belgium, Luxemburg, France, the United Kingdom, Italy and recently Spain have mainly reported cases in sheep, but also outbreaks on cattle and goat farms have been reported. In March 2012, in Germany, the Netherlands and Belgium, more than 750, 100 and 150 sheep farms respectively were found positive for the agent. Considering all these cases, it is very likely that the viral agent and the symptoms are associated. At present, viral characteristics are being de- 
termined and thorough epidemiological research is ongoing. So far, there have been no indications for direct zoonotic transmission from ruminants to humans for this new pathogen (Beer, 2011; Gibbens, 2012).

\section{BUNYAVIRIDAE: A LARGE FAMILY OF SINGLE- STRANDED AMBISENSE RNA VIRUSES}

The family Bunyaviridae comprises more than 350 viruses including both animal and plant viruses. All members are assigned to five different genera: $\mathrm{Or}$ thobunyavirus, Phlebovirus, Nairovirus, Hantavirus and Tospovirus (Weber and Elliott, 2002; Savji et al., 2011). Many bunyaviruses have no known medical or veterinary significance, but some are classified as hazard level 3 or -4 pathogens. Some of these viruses, such as Crimean-Congo hemorrhagic fever or Rift Valley fever, cause incurable hemorrhagic fever with no available preventive measures (Walter and Barr, 2011). In addition, bunyaviruses are classified as emerging pathogens due to their recent geographical movement and broadening of the host range.

All members are enveloped spherical RNA viruses of about $120 \mathrm{~nm}$ in diameter. They all possess a tri-segmented single-stranded genome and each of the segments, L (large), M (medium) and S (small) is contained in a separate capsid within the virion. Although these viruses predominantly use a negative coding strategy during their cytoplasmic replication, some genomic parts consist of ambisense RNA, which allows bi-directional coding. They encode for four structural proteins: the viral polymerase (L), glycoproteins Gn and $\mathrm{Gc}$, and the nucleocapsid $(\mathrm{N})$ protein. The open reading frames (ORFs) for these proteins are located on the L, the $\mathrm{M}$ and the $\mathrm{S}$ segments, respectively. Some viruses possess additional ORFs on either the $\mathrm{M}$ or $\mathrm{S}$ segment, encoding non-structural proteins that are designated NSm and NSs, respectively. The surface proteins Gn and Gc play a role in the attachment and fusion to the host cell and hemagglutination. However, these particular proteins also evoke a strong humoral immune response in the host that will finally eliminate the virus. Viruses within each genus may display additional similarities, such as segment size, protein size and importantly nucleotide sequence, especially at the $3^{\prime}$ and 5' ends. At these $3^{\prime}$ ' and 5' termini of the segments, high complementary, non-translated regions (NTRs) are present, allowing them to interact with one another and therefore, segments exist as circular molecules within the virion and infected cells. Furthermore, these NTRs play an important role in segment function (Weber and Elliott, 2002; Grard et al., 2011; Savji et al., 2011; Walter and Barr, 2011). A significant property of RNA viruses in general is antigenic drift. Due to the lack of a proof-reading function of the viral RNA polymerase, point mutations occur at a higher frequency than in DNA viruses. In addition, the "repair" enzyme uracil-glycosylase, active on DNA genomes, does not function on an RNA template. As a result, spontaneous deamination of cytidine residues to uracil occur more often in RNA and are another source of at random point mutations (Moutailler et al., 2011). These events lead to antigenic variation among Bunyaviridae and drive the formation of the so-called "escape mutants". These mutations enable the virus to escape from the host immune system. Additionally, bunyaviruses can exchange (part of) their genomes during a mixed infection, also known as antigenic shift. Similar to the case of Reoviridae (e.g. bluetongue virus), this genetic reassortment may lead to the generation of new variants to which the host has not been adapted yet. Alterations through both antigenic drift and antigenic shift may have a major impact on virulence, and inevitably cause emergence of new viruses (Weber and Elliott, 2002).

Bunyaviridae are transmitted by arthropods (mosquitoes, midges, ticks, thrips and sandflies), except for members of the rodent-associated genus Hantavirus. It is clear that where the vector goes, the virus will follow. Concerns have been raised over the ongoing migration of several of these vectors in more northerly regions of Europe, such as the occurrence of the Hyalomma ticks, Culicoides midges and Aedes, Culex and Anopheles mosquitoes in Europe and the subsequent increase in cases of Crimean-Congo hemorrhagic fever virus, bluetongue virus and Rift Valley fever virus infections, respectively (Mellor et al., 2008; Walter and Barr, 2011). As the newly identified virus Schmallenberg belongs to the genus Orthobunyavirus, we will focus on this genus in the present article.

\section{ORTHOBUNYAVIRUS TRANSMISSION AND EPI- DEMIOLOGY}

The Orthobunyavirus genus contains over 170 viruses which are assigned to 48 distinct species, covering 18 different serogroups. Members within each serogroup show complex antigenical relations. On the one hand, they display weak cross-reactivity in hemagglutination inhibition and antibody neutralization tests. On the other hand, they show serological relatedness by complement fixation. Importantly, most serogroups contain viruses with zoonotic potential. Based on sequence similarity, the recently isolated Schmallenberg virus is classified as a member of the Simbu serogroup. Currently, this group contains 25 different viruses isolated from arthropod and vertebrate hosts from all over the world, except Western Europe. At present, six particular members cause disease in either humans (Oropouche and Iquitos virus) or ruminants (Akabane, Aino, Shamonda and Schmallenberg virus) (Saeed et al., 2001; Mores et al., 2009; Aguilar et al., 2011; Savji et al., 2011; Gibbens, 2012).

Similar to bluetongue virus (BTV), another viral pathogen that emerged among ruminants in Western Europe in 2006, most bunyaviruses belong to the group of arthropod-borne viruses or Arboviruses (Purse et al., 2005; Mellor et al., 2008). The majority of these viruses are transmitted by different arthropods and have one or more intermediate non-human vertebrate hosts for amplifying cycles or geographical dissemi- 
nation (Hart et al., 2009; Walter and Barr, 2011). In some vector species, venereal transmission is important for spread in the insect population. In addition, vertical transmission from infected females to progeny is a cunning mechanism of the virus to overwinter and persist within the vector. So far, these two transmission mechanisms have been described for some members of the orthobunyavirus genus in mosquito vectors (Clements, 2012). An important factor in the efficient transmission is the level of viremia postinfection in vertebrates. Only if sufficient amounts of virus are circulating in the blood, the virus may reach uninfected hematophagous vectors during their blood meal and spread rapidly in herds. Therefore, humans are usually considered to be dead-end hosts. Humans may show mild illness but viral titers in the blood rarely reach high peaks (Saeed et al., 2001; Soldan and GonzálezScarano, 2005; Hart et al., 2009; Hollidge et al., 2010; Aguilar et al., 2011). So far, there have been no indications or reports of illness in humans due to Schmallenberg virus. Simbu group orthobunyaviruses are particularly associated with ceratopogonid midges such as Culicoides spp. Peak populations of the adult stage occur in late summer and autumn; therefore, acute symptoms caused by viruses transmitted by Culicoides are prevalent during that period (Mellor et al., 2008; Clements, 2012). Many different Culicoides species are vectors in the transmission of orthobunyaviruses. For example, members of the Avaritia subgenus, such as $C$. brevitarsis and $C$. imicola, are vectors for Akabane, Aino and Shamonda virus in the Mediterranean region, Africa, Japan, Australia, as well as in other places (Bishop et al., 2000; Stram et al., 2004; Yanase et al., 2004). Normally, these vectors are not present in Europe. However, the emergence of BTV, which uses similar vector species, in Western Europe in 2006, displayed an important alteration in the epidemiology of this virus. The introduction of BTV in a naive area is believed to occur in a number of different ways: these include the movement of infected animals or animal material and the movement of infected vectors, either passively (by wind, airplanes, plants, animals, etc.) or actively (climate change) with subsequent local propagation (Wittmann and Baylis, 2000; Saegerman et al., 2010). Firstly, it has been shown that, even before the BTV-8 outbreak in Northwestern Europe in 2006, important Afro-Asian vector species have migrated northwards but are not found in all the BTV-affected areas of Europe (Wittmann and Baylis, 2000; Purse et al., 2005; Mellor et al., 2008). Both climate change and increasing international travel and transport seem to be responsible for this ongoing vector migration (Walter and Barr, 2011). Secondly and more importantly, other Culicoides species, including other members of the previously mentioned Avaritia subgenus all of which are endemic in most parts of Northwestern Europe, were responsible for the BTV-8 transmission in 2006 (Meiswinkel et al., 2008a, 2008b; Vanbinst et al., 2009). Although a variety of mammal and avian species may be targeted by these European endemic midges, cattle have been shown to be the preferred host for blood meals (Bartsch et al., 2009; Lassen et al., 2011).

PATHOGENESIS AND CLINICAL MANIFESTATIONS CAUSED BY THE SIMBU SEROGROUP

The outcome of infection is different for invertebrates compared to vertebrates. Although the virus replicates cytoplasmically, infection of mammalian cells is cytolytic and results in cell death, whereas infection of insect cells leads to persistence as no cytopathic effects are visible postinfection (Hart et al., 2009).

The initial replication of the virus inside the vector occurs in the midgut epithelium. Subsequently, the virus disseminates into the hemocoel, permitting carriage in the hemolymph. Finally, the virus enters cells of the salivary glands, replicates and reaches the salivary ducts (Clements, 2012). In ruminants, bunyaviruses replicate in the periphery and cause a subsequent transient viremia in their hosts. For Simbu group viruses, Akabane virus is probably the best-studied member of the viruses that may cause disease in ruminants.

During the acute onset of infection with Akabane virus in adult cattle, there are usually no overt clinical signs. Viremia generally occurs one to six days after infection and may last for two to six days (Charles, 1994). However, Schmallenberg virus seems to have a more clinical acute onset, as is the case for Rift Valley fever virus (RVFV) (Table 1). RVFV is a bunyavirus that causes inappetence, diarrhea and fever among other symptoms in cattle during the acute phase of infection (Hollidge et al., 2010; Beer, 2011). Interestingly, the level and severity of viremia often seem to be age-dependent. Newborn animals develop higher titers of viremia than adult animals (Weber and Elliott, 2002). However, a large-scale outbreak in Japan of neurological symptoms in beef and dairy cattle of 4 to 96 months of age showed that virulent isolates that induce a strong viremia are not age-restricted (Kono et al., 2008). Because of the high plasma load, the virus is able to cross the blood-brain barrier through an unknown mechanism and cause severe encephalomyelitis and death (Weber and Elliott, 2002). Both innate and specific humoral immunity are important factors for viral clearance. Cell-mediated immunity seems to play a minor role because infected cells are rapidly destroyed by the viral infection itself (Pavlovic et al., 2000). Type I interferon (IFN), produced by infected cells, plays a major role in controlling the first critical viremic phase of Bunyaviridae. As part of the innate (aspecific) immunity, IFN primes neighboring cells to express antiviral factors and therefore establishes a first line of defense. In newborn animals, the interferon system is not yet fully matured, which may in part explain the higher viremic load. If the host is able to confine the virus, the adaptive immune system produces specific neutralizing antibodies that are involved in the viral clearance and the protection against recurrent infections (Weber and Elliott, 2002).

In pregnant cattle however, the short viremic phase 
Table 1. Comparison of two closely related Simbu group orthobunyaviruses in ruminants.

\begin{tabular}{|c|c|c|}
\hline & Akabane virus & Schmallenberg virus \\
\hline Genus & Orthobunyavirus & Orthobunyavirus \\
\hline Serogroup & Simbu & Simbu \\
\hline Geographical location & Africa, Asia and Oceania & Europe \\
\hline Vector & $\begin{array}{c}\text { Culicoides imicola } \\
\text { Culicoides brevitarsis } \\
\text { Culicoides wadei } \\
\text { Culicoides oxystoma } \\
\text { Culicoides milnei } \\
\text { (Aedes, Culex and Anopheles) }\end{array}$ & $\begin{array}{c}\text { Culicoides obsoletus } \\
\text { Culicoides dewulfi } \\
\text { Culicoides pulicaris } \\
\text { Culicoides imicola? } \\
\text { Aedes, Culex and Anopheles? }\end{array}$ \\
\hline Host range & $\begin{array}{c}\text { Cattle } \\
\text { Sheep } \\
\text { Goats } \\
\text { Wild ruminants } \\
\text { (Dogs, Horses, Camels) }\end{array}$ & $\begin{array}{l}\text { Cattle } \\
\text { Sheep } \\
\text { Goats } \\
\text { ? }\end{array}$ \\
\hline Incubation period & 1-6 days & $?$ \\
\hline Viremia duration & 4-6 days & 2-6 days \\
\hline Acute symptoms (adult animals) & Subclinical & $\begin{array}{l}\text { In cattle: high fever }\left(>40,5^{\circ} \mathrm{C}\right) \text {, } \\
\text { loss of appetite, loss of condition, } \\
\text { milk drop, diarrhea }\end{array}$ \\
\hline \multirow[t]{3}{*}{ Effect on fetus (symptoms) } & $\begin{array}{l}\text { Arthrogryposis, torticollis, } \\
\text { scoliosis, kyphosis, } \\
\text { brachygnathism, muscular hypoplasia, } \\
\text { fibrinous polyarticular synovitis }\end{array}$ & $\begin{array}{c}\text { Arthrogryposis, torticollis, } \\
\text { scoliosis, kyphosis, } \\
\text { brachygnathism, muscular hypoplasia } \\
+?\end{array}$ \\
\hline & $\begin{array}{l}\text { Hydranencephaly, microencephaly, } \\
\text { porencephaly, agenesis of the cerebrum, } \\
\text { hydrocephalus, fibrinous leptomeningitis } \\
\text { and ependymitis, agenesis/hypoplasia } \\
\text { of the spinal cord }\end{array}$ & $\begin{array}{l}\text { Hydranencephaly, microencephaly, } \\
\text { porencephaly, agenesis of the } \\
\text { cerebrum and possible cerebellum, } \\
\text { hydrocephalus, agenesis/hypoplasia } \\
\text { of the spinal cord } \\
+?\end{array}$ \\
\hline & $\begin{array}{l}\text { Lung hypoplasia, } \\
\text { fibrinous navel infection, } \\
\text { erosions muzzle and interdigital erosions, } \\
\text { cataract, presternal steatosis }\end{array}$ & $\begin{array}{l}\text { Lung hypoplasia } \\
\qquad+?\end{array}$ \\
\hline Diagnosis & $\begin{array}{c}\text { Virus isolation, RT-PCR, HI, } \\
\text { SN, ELISA }\end{array}$ & $\begin{array}{l}\text { Virus isolation, RT-PCR } \\
\text { (serology) }\end{array}$ \\
\hline Vaccines & Yes & Not yet \\
\hline
\end{tabular}

creates a small opportunity for the virus to reach the fetal circulation, thereby infecting the placenta. The virus then multiplies in the rapidly dividing cells of the fetus, especially in the fetal brain, spinal cord and skeletal muscle (Parsonson et al., 1982, 1988). For neuronal tissues, it has been shown that neuronal and astroglia cells are particularly susceptible to Akabane virus infection, whereas microglia cells seem rather resistant to infection (Kitani et al., 2000). The time of infection relative to the stage of gestation determines the severity of developmental defects. When neuronal tissues are differentiating, maximal damage occurs at approximately 30-50 days, 40 days and 60-90 days in pregnant sheep, pregnant goats and pregnant cattle respectively. The duration of infection of the fetus is de- pendent on the ability of the fetal immune system to react upon infection. Immunocompetence in calves develops at approximately 90 days of gestation and in lambs at 65 to 70 days of gestation (Parsonson et al., $1977,1981,1985)$. The manifestation of the virus in the fetus may result in various clinical symptoms, which are quite similar for Akabane and Schmallenberg virus (Figures 1 to 7 ). Abortion in the third trimester might be observed in case of acute infection of pregnant animals. However, most symptoms are seen some time after initial infection in the dam. They include abortion, stillborn calves or calves that are delivered alive premature or at term, with various intrauterine congenital malformations. As mentioned above, fetal damage is dependent on the time of in- 


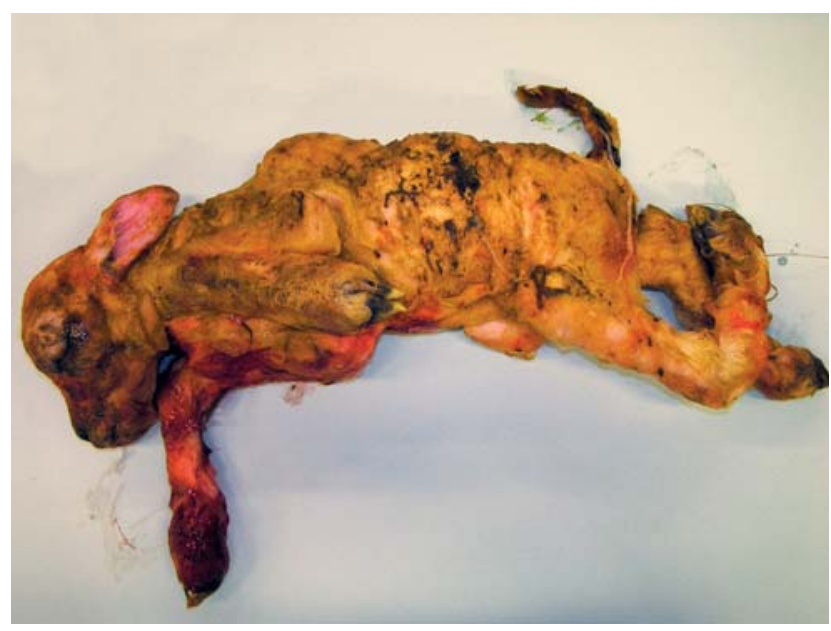

Figure 1. Typical clinical image of a newborn affected by Schmallenberg virus infection.

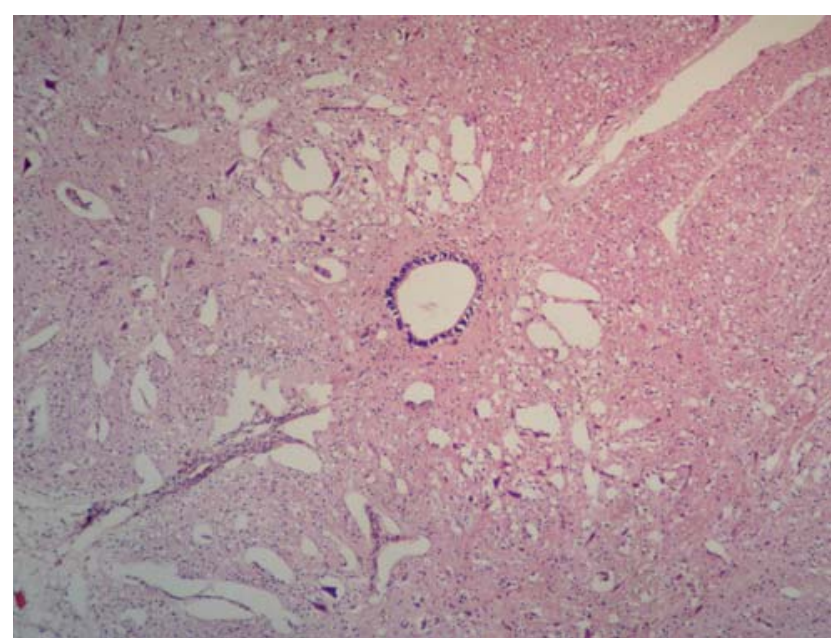

Figure 3. Histopathological image of the spinal cord of a lamb affected by Schmallenberg virus. Although the central canal is clearly visible, severe neuronal loss in both dorsal and ventral gray matter of the spinal cord are prominent.

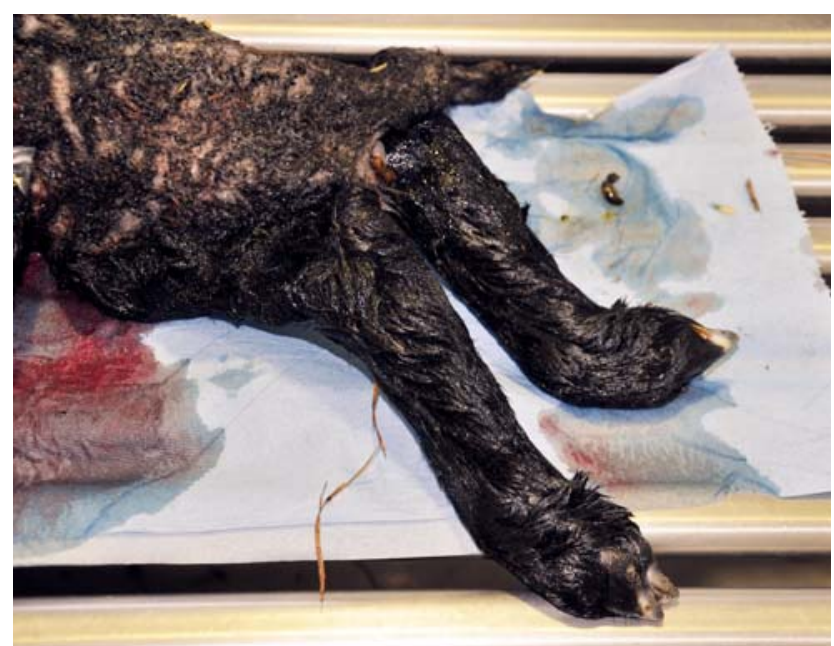

Figure 5. Severe arthrogryposis in a newborn lamb caused by Schmallenberg virus. Notice the severe ankylotic joints in the hind limbs. (Picture by K. Van der Sypt)

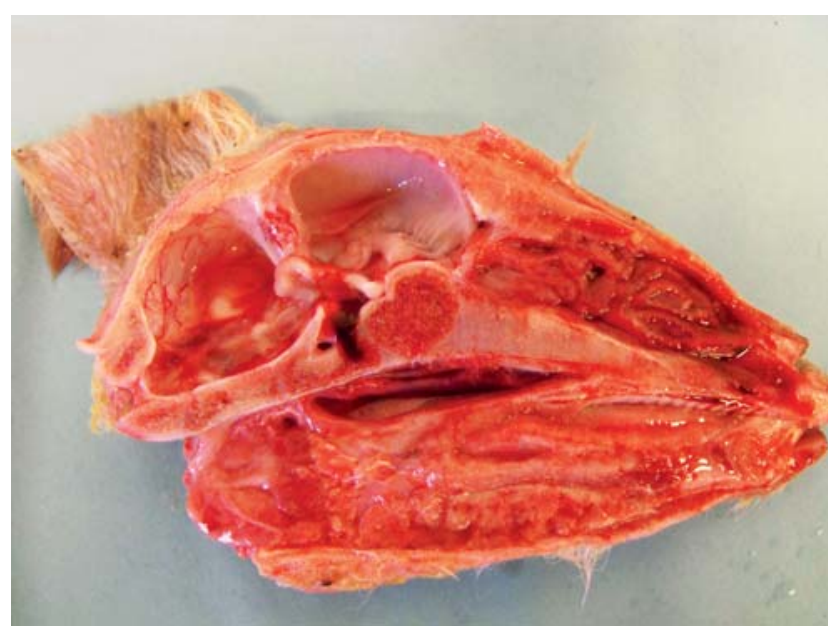

Figure 2. Hydranencephaly caused by Schmallenberg virus in a newly born lamb.

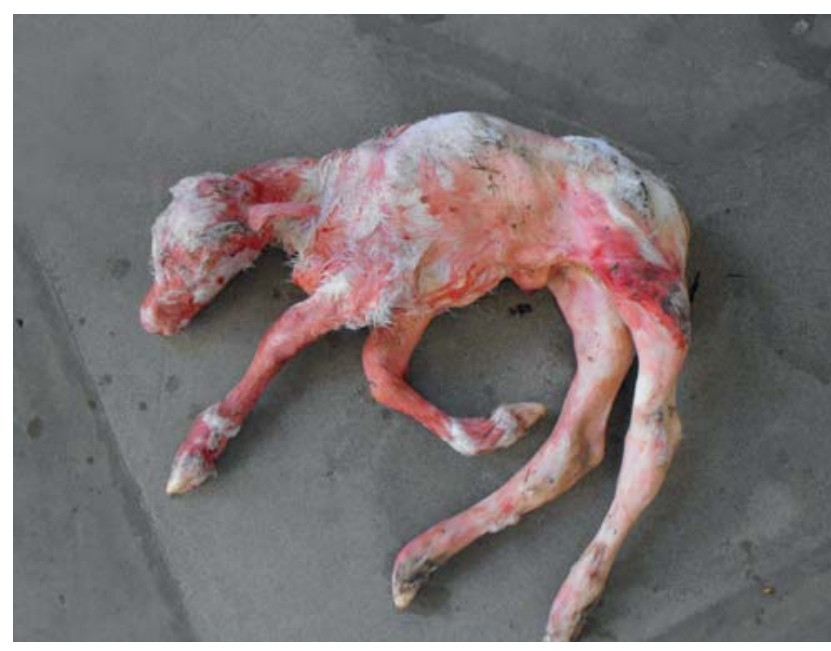

Figure 4. Intra-uterine Schmallenberg virus infection of a neonatal calf.

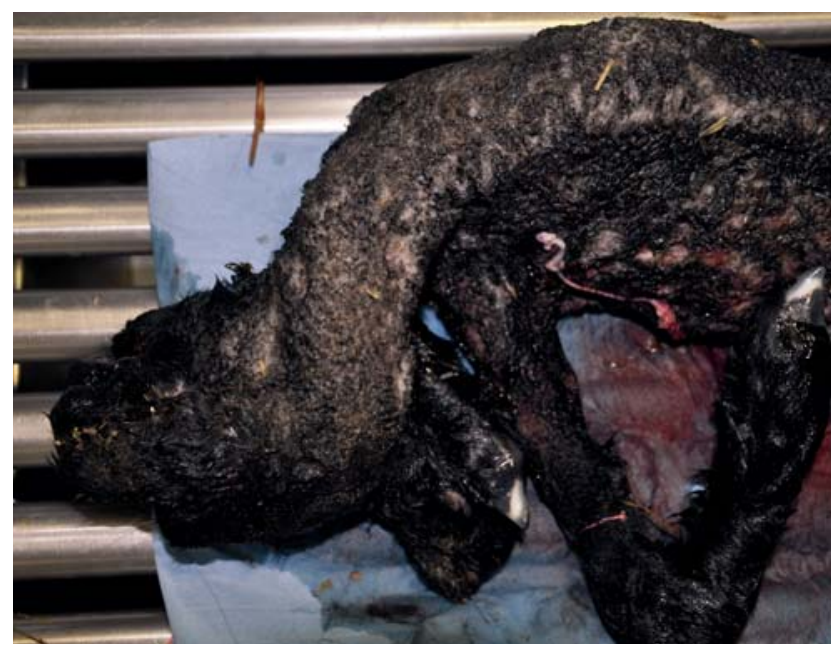

Figure 6. Torticollis is often present due to infection with Schmallenberg virus, as seen in this newborn lamb. (Picture by K. Van der Sypt) 


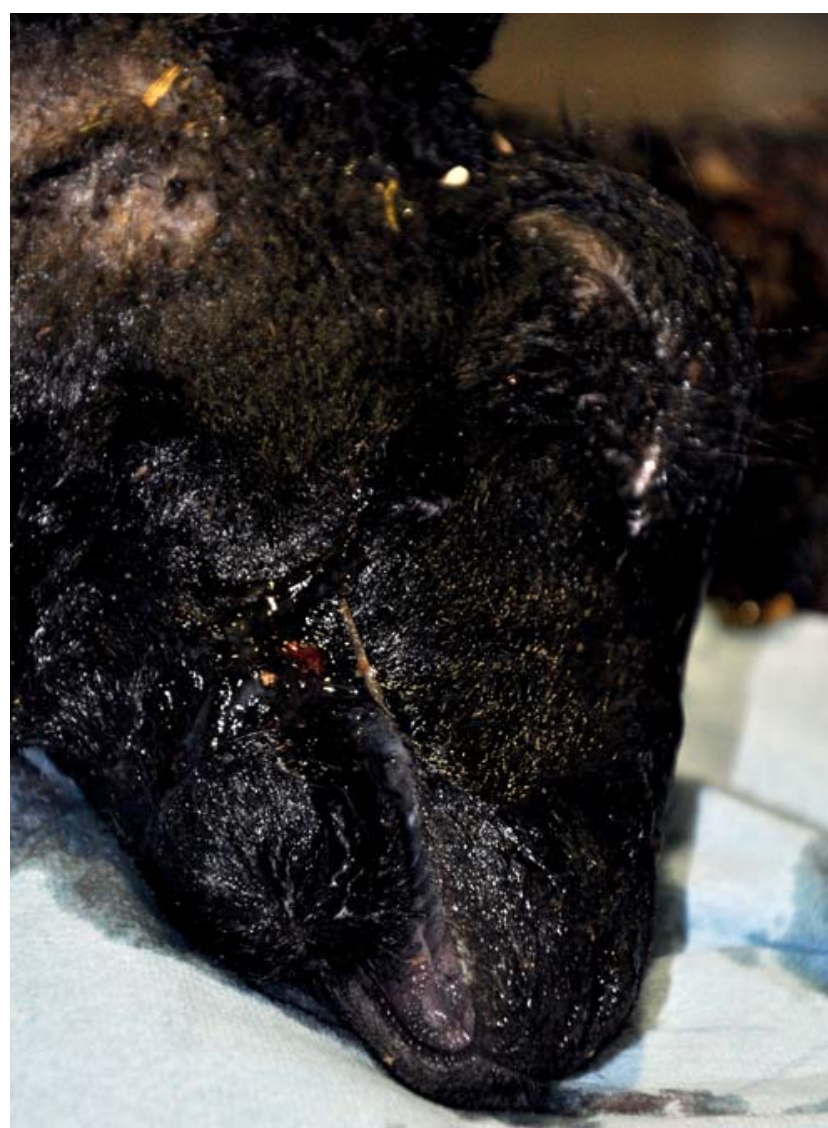

Figure 7. Newborn lamb showing severe inferior brachygnathism due to Schmallenberg virus infection in utero. (Picture by K. Van der Sypt)

fection during gestation. Infection during the first trimester results in grossly deformed fetuses, mostly dead at birth with limbs locked in extension or flexion. Most live neonates have central nervous disorders ranging from dullness, blindness and deafness to severe paralysis and incoordination. Within the central nervous system, hydranencephaly, hydrocephalus, agenesis of the brain, microencephaly, porencephaly and cerebellar cavitation, etc. have been variously reported. The cerebellum however, remains unaffected after Akabane infection, but Schmallenberg virus can cause agenesis or hypoplasia of the cerebellum. Additionally, musculoskeletal abnormalities, including arthrogryposis, torticollis, scoliosis, brachygnathism and kyphosis, are often observed. Veterinarians should remain vigilant of the fact that dystocia at parturition may occur owing to the deformities in the fetus (Whittem, 1957; Kurogi et al. , 1977; Parsonson et al., 1977, 1981). The final clinical image of a newborn depends on how many limbs are involved and, more importantly, how many of the higher functions are impaired because of the brain lesions. Even when the cerebrum is entirely absent, all vital functions may be intact and the neonates can possibly stand and walk independently. Exceptionally, some of them have been reared to maturity and have calved in a normal way (Parsonson et al., 1977, 1981).

\section{DIAGNOSIS AND DIFFERENTIAL DIAGNOSIS}

A sudden onset of clustered cases of abortion, premature and at term, live or stillborn fetuses with arthrogryposis and hydranencephaly suggests a teratogenic virus as possible cause. Next to orthobunyaviruses, bluetongue virus, bovine viral diarrhea virus and border disease virus causing hydranencephaly, cerebellar dysplasia and hairy shaker lambs respectively, should be considered as potential causative agents (Osburn and Castrucci, 1991; Nettleton et al., 1998; Vercauteren et al., 2008; De Clercq et al., 2008). The results of diagnostic tests and the subclinical or mild clinical symptoms in the dam are suggestive for Orthobunyavirus infection.

The detection of virus specific antibodies is often used as a diagnostic tool and is useful in virus epidemiology. Seroconversion in the dam and the presence of antibodies in precolostral fetal serum confirm recent bunyavirus infection. Serum neutralization (SN) and hemagglutination inhibition (HI) tests have been used extensively for this purpose and have proved to be specific and sensitive, especially SN. In addition, different enzyme-linked immunosorbent assays (ELISAs) are available. However, in view of cross reactivity and diagnostic accuracy, it is important to validate these tests (Tsuda et al., 2004; Paweska et al., 2007).

For etiological diagnosis, traditional virus isolation from placenta and affected fetal tissues, such as nervous tissues and cerebrospinal fluid, may be considered, although it rarely generates a positive result. If adult animals show clinical symptoms during the acute stage of infection, virus isolation from blood samples might show positive results. Cell lines derived from different species are susceptible to bunyaviruses. Simbu group orthobunyaviruses can be grown on monkey kidney (Vero), hamster lung (HmLu-1) and baby hamster kidney (BHK-21) cells, among others (Coetzer and Tustin, 2004; Aguilar et al., 2011; Kim et al., 2011). Diagnostics for detection of the virus can also be performed by using reverse transcriptase polymerase chain reaction (RT-PCR), both conventional and quantitative. Moreover, RT-PCR is a rapid and sensitive method that is being increasingly used as a supplement to serology for the diagnosis of Arboviruses (Wang et al., 2009).

\section{CONTROL AND ERADICATION}

At present, no therapeutics are available for bunyavirus-induced diseases and supportive treatment is limited. Although some bunyaviruses seem to be hampered by the antiviral drug ribavirin, the majority, including Simbu group orthobunyaviruses, remain unaffected (Livonesi et al., 2006; Flusin et al., 2011). Interestingly, RNA interference by siRNAs has been shown to be a potential candidate to interfere with infections caused by Bunyaviridae including Akabane virus (Levin et al., 2006). However, especially for livestock, prophylactic measures remain of major importance for practical and economical reasons. In Korea and Japan, vaccines against Akabane virus are 
commercially available (Kim et al., 2011). In Australia, an effective killed vaccine against Akabane virus has been developed but has not been marketed yet (Kirkland and Barry, 1986). The purpose of these vaccines is to induce specific neutralizing antibodies against the virus in the dam, thereby preventing the virus from reaching the fetus. Studies conducted with La Crosse virus, an orthobunyavirus within the California serogroup, have shown that especially glycoprotein G1 induces neutralizing antibodies that give a protective immune response (Pekosz et al., 1995). Importantly, animals that are naturally infected with Akabane virus, seem to develop a strong immunity which may last for a few years. Therefore, an alternative strategy is to move susceptible animals to endemic regions to develop immunity before they are first bred. Moreover, for neonatal calves, especially for beef calves, it has been shown that Akabane specific antibody enriched colostrum provides a decent maternal immunity. Approximately 4.8 months is the estimated age when the maternal antibodies decay with a $90 \%$ probability (Tsutsui et al., 2009). Vaccines should be administered before and during gestation, prior to the exposure to infected vectors, in order to be efficacious. Other preventive measures focus on control of the vector. Disruption of breeding sites, reduction of vector population through pesticide use and protection of ruminants by repellents are possible additional measures but are more labor intensive (Clements, 2012).

\section{ZOONOTIC POTENTIAL}

At least 30 different orthobunyaviruses may cause disease in humans, and symptoms range from mild febrile illness to severe encephalitis and hemorrhagic fever. The symptoms in humans are mainly observed during the period of vector activity. In most cases however, humans are accidentally infected by the vector and thus considered to be dead-end hosts, showing mild illness and a low viremia. Subsequently, further spread to uninfected vectors and humans is not observed. Exceptions may be found within the Simbu serogroup orthobunyaviruses. Oropouche and Iquitos viruses are causative agents of large epidemics of febrile illness among humans (Hart et al., 2009; Aguilar et al., 2011). So far, other members of the Simbu group, such as Akabane, Aino and Shamonda, have only been found in livestock. Nevertheless, as a group, orthobunyaviruses have zoonotic potential because a large number of orthobunyaviruses can cause disease among humans. Therefore, zoonotic potential cannot be excluded, although it is unlikely (Hart et al., 2009). Interestingly, the non-structural protein NSs is responsible for antagonizing the IFN response during infection. As the ability to counteract and overcome the host innate immune response is considered to be of importance for delineating host range, the NSs protein is a factor that drives the zoonotic capacity of orthobunyaviruses (Hart et al., 2009). So far, no unusual illness in humans due to the Schmallenberg virus has been reported.

\section{CONCLUSIONS AND FUTURE DIRECTIONS}

The emergence of Schmallenberg virus among ruminants in Western Europe, an Akabane-like Simbu group Orthobunyavirus, confirmed once again that Arboviruses are excellent paradigms for emerging and reemerging diseases. Different factors, such as vector/host dynamics, climate and immune status of the population, play a role in the Arbovirus life cycle. Climate change is thought to be a key player in spread of Arboviruses. A higher average temperature increases vector populations, and more importantly, allows changes in vector range and vertebrate hosts (Hollidge et al., 2010). Since the emergence of bluetongue in 2006, it has become clear that, despite the clear expansion northwards of $C$. imicola, which had already been observed before 2006, the range of BTV has spread beyond the range of this Afro-Asian vector, thereby suggesting that novel vector species might be contributing to transmission. Recent studies have confirmed that endemic Culicoides contribute to the observed spread (Meiswinkel et al., 2008a, 2008b; Vanbinst et al., 2009). Although speculative at the moment, it is very plausible that the evolution of the spread of Schmallenberg virus and that of bunyaviruses in general are very similar.

At present, it is still unclear whether this exotic virus has been newly introduced or whether orthobunyaviruses have already been present in ruminants and vectors in Europe for some time. To address this question, it might be worth reinvestigating the acquired vectors from the BTV vector surveys for Orthobunyavirus presence. Another interesting question is how spread from the tropical vector to the endemic vector exactly happens. A straightforward approach would be to introduce the virus in a naive vector population, which may be susceptible to sustain infection but which has never been exposed to this virus family before. However, if endemic Culicoides do not possess correct entry receptors for those viruses, mating of local species with the newly immigrant tropical vectors might result in hybrid progeny that allows viral infection and subsequent persistence. Elucidating these aspects may be instrumental in attaining better control of these emerging diseases.

Stimulating immunity by use of vaccines is another way of controlling viruses. Humoral immunity plays a major role in controlling orthobunyaviruses, and for certain Simbu group members such as Akabane virus vaccines have been developed (Kim et al., 2011). However, the production of vaccines takes time, and importantly, vaccines must be safe and their use needs to be economically justified. Considering the epidemiology of Schmallenberg virus, the virus is likely to recur during the vector season of 2012. In this event, it will be important to monitor these expected outbreaks.

There is an urgent need for profound research to improve the present knowledge in order to solve ambiguities such as: are animals that were infected in 2011 immune and (lifelong) protected? Are vaccines neces- 
sary, if natural infection may occur and immunize animals before fertilization and gestation? May the virus be transmitted through contact with for instance amniotic fluid? May zoonotic transmission of Schmallenberg virus be firmly excluded?

\section{ACKNOWLEDGEMENTS}

The authors would like to thank veterinarian $\mathrm{K}$. Van der Sypt for providing pictures of clinical cases of Schmallenberg virus infection. The authors also thank Dr. M. Leelawong native English speaker, for proofreading and critical analysis of the manuscript.

\section{REFERENCES}

Aguilar P.V., Barrett A.D., Saeed M.F., Watts D.M., Russell K., Guevara C., Ampuero J.S., Suarez L., Cespedes M., Montgomery J.M., Halsey E.S., Kochel T.J. (2011). Iquitos virus: a novel reassortment Orthobunyavirus associated with human illness in Peru. PLoS Neglected Tropical Diseases 5, e1315.

Bartsch S., Bauer B., Wiemann A., Clausen P.H., Steuber S. (2009). Feeding patterns of biting midges of the Culicoides obsoletus and Culicoides pulicaris groups on selected farms in Brandenburg, Germany. Parasitology Research 105, 373-380.

Beer M. (2011) Undiagnosed illness, bovine-Germany, Netherlands (02): new virus susp. ProMED-mail 2011, Archive nr. 20111119.3404.

Bishop A.L., Barchia I.M., Spohr L.J. (2000). Models for the dispersal in Australia of the arbovirus vector, Culicoides brevitarsis Kieffer (Diptera: Ceratopogonidae). Preventive Veterinary Medicine 47, 243-254.

Charles J.A. (1994). Akabane virus. Veterinary Clinics of North America: Food Animal Practice 10, 525-546.

Clements A.N. (2012). Arboviruses - characteristics and concepts. In: Clements A.N. (editor). The Biology of Mosquitoes, Vol. 3, Transmission of viruses and interactions with bacteria. Chambridge University Press, Chambridge, p. 90-173.

Coetzer J.A.W., Tustin R.C. (2004). Viral diseases: Bunyaviridae. In: Coetzer J.A.W. and Tustin R.C. (editors). Infectious Diseases of Livestock. $2^{\text {nd }}$ Edition, Vol. 2, Oxford University Press, Oxford, p. 1029-1036.

De Clercq K., De Leeuw I., Verheyden B., Vandemeulebroucke E., Vanbinst T., Herr C., Méroc E., Bertels G., Steurbaut N., Miry C., De Bleecker K., Maquet G., Bughin J., Saulmont M., Lebrun M., Sustronck B., De Deken R., Hooyberghs J., Houdart P., Raemakers M., Mintiens K., Kerkhofs P., Goris N., Vandenbussche F. (2008). Transplacental infection and apparently immunotolerance induced by a wild-type Bluetongue virus serotype 8 natural infection. Transboundary and Emerging Diseases 55, 352-359.

Flusin O., Vigne S., Peyrefitte C.N., Bouloy M., Crance J.M., Iseni F. (2011). Inhibition of Hazara nairovirus replication by small interfering RNAs and their combination with ribavirin. Virology Journal 8, 249.

Gibbens N. (2012). Schmallenberg virus: a novel viral disease in northern Europe. Veterinary Record, doi:10.1136/vr.e292.

Grard G., Drexler J.F., Fair J., Muyembe JJ., Wolfe N.D., Drosten C., Leroy E.M. (2011). Re-emergence of Crimean-Congo Hemorrhagic Fever virus in Central Africa. PLoS Neglected Tropical Diseases 5, e1350.
Hart T.J., Kohl A., Elliott R.M. (2009). Role of the NSs protein in the zoonotic capacity of orthobunyaviruses. Zoonoses and Public Health 56, 285-296.

Hollidge B.S., González-Scarano F., Soldan S.S. (2010). Arboviral encephalitides: transmission, emergence, and pathogenesis. Journal of Neuroimmune Pharmacology 5 , 428-442.

Kim YH., Kweon CH., Tark DS., In Lim S., Yang DK., Hyun BH., Song JY., Hur W., Park S. C. (2011). Development of inactivated trivalent vaccine for the teratogenic Aino, Akabane and Chuzan viruses. Biologicals 39, 152-157.

Kirkland P.D., Barry R.D. (1986). The economic impact of Akabane virus and the cost effectiveness of vaccination in New South Wales. In: Proceedings of the $4^{\text {th }}$ symposium on Arbovirus Research Australia 4, 229-232.

Kitani H., Yamakawa M., Ikeda H. (2000). Preferential infection of neuronal and astroglia cells by Akabane virus in primary cultures of fetal bovine brain. Veterinary Microbiology 73, 269-279.

Kono R., Hirata M., Kaji M., Goto Y., Ikeda S., Yanase T., Kato T., Tanaka S., Tsutsui T., Imada T., Yamakawa M. (2008). Bovine epizootic encephalomyelitis caused by Akbane virus in southern Japan. BMC Veterinary Research 4, 20.

Kurogi H., Inaba Y., Takahashi E., Sato K., Satoda K., Goto Y., Omori T., Matumoto M. (1977). Congenital abnormalities in newborn calves after inoculation of pregnant cows with Akabane virus. Infection and Immunity 17, 338-343.

Lassen S.B., Nielsen S.A., Skovgard H., Kristensen M. (2011). Molecular identification of blood meals from biting midges (Diptera: Ceratopogonidae: Culicoides Latreille) in Denmark. Parasitology Research 108, 823-829.

Levin A., Kutznetova L., Kahana R., Rubinstein-Guini M., Stram Y. (2006). Highly efficient inhibition of Akabane virus replication by siRNA genes. Virus Research 120, 121-127.

Livonesi M.C., De Sousa R.L., Badra S.J., Figueiredo L.T. (2006). In vitro and in vivo studies of ribavirin action on Brazilian Orthobunyavirus. American Journal of Tropical Medicine and Hygiene 75, 1011-1016.

Meiswinkel R., Baldet T., de Deken R., Takken W., Delecolle J.C., Mellor P.S. (2008a). The 2006 outbreak of bluetongue in northern Europe - the entomological perspective. Preventive Veterinary Medicine 87, 55-63.

Meiswinkel R., Goffredo M., Leijs P., Conte A. (2008b). The Culicoides 'snapshot': a novel approach used to assess vector densities widely and rapidly during the 2006 outbreak of bluetongue (BT) in the Netherlands. Preventive Veterinary Medicine 87, 98-118.

Mellor P.S., Carpenter S., Harrup L., Baylis M., Mertens P.P.C. (2008). Bluetongue in Europe and the Mediterranean Basin: history of occurrence prior to 2006. Preventive Veterinary Medicine 87, 4-20.

Mores C.N., Turell M.J., Dyer J., Rossi C.A. (2009). Phylogenetic relationships among orthobunyaviruses isolated from mosquitoes captured in Peru. Vector Borne Zoonotic Diseases 9, 25-32.

Moutailler S., Roche B., Thiberge JM., Caro V., Rougeon F., Failloux AB. (2011). Host alternation is necessary to maintain the genome stability of Rift Valley Fever virus. PLoS Neglected Tropical Diseases 5, e1156.

Nettleton P.F., Gilray J.A., Russo P., Dlissi E. (1998). Border disease of sheep and goats. Veterinary Research 29, 327-340.

Osburn B.I., Castrucci G. (1991). Diaplacental infections with ruminant pestiviruses. Archives of Virology 3, 71-78. 
Parsonson I.M, Della-Porta A.J., Snowdon W.A. (1977). Congenital abnormalities in newborn lambs after infection of pregnant sheep with Akabane virus. Infection and Immunity 15, 254-262.

Parsonson I.M., Della-Porta A.J., Snowdon W.A. (1981). Developmental disorders of the fetus in some arthropodborne virus infections. American Journal of Tropical Medicine and Hygiene 30, 660-673.

Parsonson I.M., Della-Porta A.J., McPhee D.A. (1982). Pathogenesis and virulence studies of Australian Simbu serogroup Bunyaviruses. In: Mackenzie J. (ed.). Viral Diseases in South-East Asia and the Western Pacific. Academic press, Sydney.

Parsonson I.M, McPhee D.A. (1985). Bunyavirus pathogenesis. Advances in Virus Research 40, 279-316.

Parsonson I.M., McPhee D.A., Della-Porta A.J., McClure S., McCullagh P. (1988). Transmission of Akabane virus from the ewe to the early fetus ( 32 to 53 days). Journal of Comparative Pathology 98, 215-227.

Pavlovic A., Schultz J., Hefti H.P., Schuh T., Molling K. (2000). DNA vaccination against Lacrosse virus. Intervirology 43, 312-321.

Paweska J.T., Jansen van Vuren P., Swanenpoel R. (2007). Validation of an indirect ELISA based on a recombinant nucleocapsid protein of Rift Valley fever virus for the detection of IgG antibody in humans. Journal of Virological Methods 146, 119-124.

Pekosz A., Griot C., Stillmock K., Nathanson N., GonzálezScarano F. (1995). Protection from La Crosse virus encephalitis with recombinant glycoproteins: Role of neutralizing anti-G1 antibodies. Journal of Virology 69, 3475-3481.

Purse B.V., Mellor P.S., Rogers D.J., Samuel A.R., Mertens P.P., Baylis M. (2005). Climate change and the recent emergence of bluetongue in Europe. Nature Reviews Microbiology 3, 171-181.

Saeed M.F., Li L., Wang H., Weaver S.C., Barrett A.D.T. (2001). Phylogeny of the Simbu serogroup of the genus Bunyavirus. Journal of General Virology 82, 2173-2181.

Saegerman C., Mellor P., Uyttenhoef A., Hanon JB., Kirschvink N., Haubruge E., Delcroix P., Houtain JY., Pourquier P., Vandenbussche F., Verheyden B., De Clercq K., Czaplicki G. (2010). The most likely time and place of introduction of BTV8 into Belgian Ruminants. PLoS One 5 , e9405.

Savji N., Palacios G., Travassos da Rosa A., Hutchinson S., Celone C., Hui J., Briese T., Calisher C.H., Tesh R.B., Lipkin W.I. (2011). Genomic and phylogenetic characterization of Leanyer virus, a novel orthobunyavirus isolated in northern Australia. Journal of General Virology 92, 1676-1687.
Soldan S.S., González-Scarano F. (2005). Emerging infectious diseases: The Bunyaviridae. Journal of Neurovirology 11, 412-423.

Stram Y., Brenner J., Braverman Y., Banet-Noach C., Kuznetzova L., Ginni M. (2004). Akabane virus in Israel: a new virus lineage. Virus Research 104, 93-97.

Tsuda T., Yoshida K., Yanase T., Ohashi S., Yamakawa M. (2004). Competitive enzyme-linked immunosorbent assay for the detection of the antibodies specific to Akabane virus. Journal of Veterinary Diagnostic Investigation 16, 571-576.

Tsutsui T., Yamamoto T., Hayama Y., Akiba Y., Nishiguchi A., Kobayashi S., Yamakawa M. (2009). Duration of maternally derived antibodies against Akabane virus in calves: survival analysis. Journal of Veterinary Medical Science 71, 913-918.

Vanbinst T., Vandenbussche F., Vandemeulebroucke E., De Leeuw I., Deblauwe I., De Deken G., Madder M., Haubruge E., Losson B., De Clercq K. (2009). Bluetongue virus detection by real-time RT-PCR in Culicoides captured during the 2006 epizootic in Belgium and development of an internal control. Transboundary and Emerging Diseases 56, 170-177.

Vercauteren G., Miry C., Vandenbussche F., Ducatelle R., Van der Heyden S., Vandemeulebroucke E., De Leeuw I., Deprez P., Chiers K., De Clercq K. (2008). Bluetongue virus serotype 8 -associated congenital hydranencephaly in calves. Transboundary and Emerging Diseases 55, 293 298.

Walter C.T., Barr J.N. (2011). Recent advances in the molecular and cellular biology of bunyaviruses. Journal of General Virology 92, 2467-2484.

Wang H., Nattanmai S., Kramer L.D., Bernard K.A., Tavakoli N.P. (2009). A duplex real-time reverse transcriptase polymerase chain reaction assay for the detection of California serogroup and Cache Valley viruses. Diagnostic Microbiology and Infectious Disease 65, 150-157.

Weber F., Elliott R.M. (2002). Antigenic drift, antigenic shift and interferon antagonists: how bunyaviruses counteract the immune system. Virus Research 88, 129-136.

Whittem J.H. (1957). Congenital abnormalities in calves: arthrogryposis and hydranencephaly. Journal of Pathology and Bacteriology 73, 375-387.

Wittmann E.J., Baylis M. (2000). Climate change: effects on Culicoides-transmitted viruses and implications for the UK. The Veterinary Journal 160, 107-117.

Yanase T., Maeda K., Kato T., Nyuat S., Kamata H., Yamakawa M., Tsuda T. (2004). The resurgence of Shamonda virus, an African Simbu group virus of the genus Orthobunyavirus, in Japan. Archives of Virology 150, 361369. 